\title{
INTRAPRENEURS AND ENTREPRENEURS - DO THEY DIFFER IN ROMANIA?
}

\author{
Annamária DÉZSI-BENYOVSZKI - Tünde Petra SZABÓ
}

(Received: 20 December 2015; 1 November 2016; accepted: 18 January 2017)

This study focuses on the theory of planned behaviour in order to understand and to predict the entrepreneurial behaviour of Romanian early-stage entrepreneurs and intrapreneurs, identifying the main differences among them. We first present the individual level analysis of these new venture creators using the Global Entrepreneurship Monitor (GEM) Adult Population Survey database of Romania from 2011 to 2014, followed by the estimation of logistic regressions in order to test the applicability of the theory of planned behaviour in predicting entrepreneurial behaviour. We aim to contribute to the understanding of differences in start-up activities by broadening the concept of start-up to include intrapreneurship as well. The findings of this study provide partial support of the theory of planned behaviour.

Keywords: intrapreneur, entrepreneur, early-stage entrepreneur, Global Entrepreneurship Monitor, theory of planned behaviour

JEL classification indices: J24, L26, M13

Annamária Dézsi-Benyovszki, corresponding author. Associate professor at the Babeş-Bolyai University, Faculty of Economics and Business Administration, Cluj-Napoca, Romania.

E-mail: annamaria.benyovszki@econ.ubbcluj.ro

Tünde Petra Szabó, Associate Professor at the Babeş-Bolyai University, Faculty of Economics and Business Administration, Cluj-Napoca, Romania. E-mail: petra.szabo@econ.ubbcluj.ro 


\section{INTRODUCTION}

Entrepreneurship and intrapreneurship contribute to the economic growth and development of an economy through value creation, innovation, job creation, and competitiveness. Due to this important role, it is crucial to understand both types of entrepreneurs. One of the main concerns related to intrapreneurship and entrepreneurship was formulated in 1985 by Gifford Pinchot. Since then, this field of research has been widely debated.

Two models dominate the literature of entrepreneurial behaviour: the entrepreneurial event model and the theory of planned behaviour. The first model, constructed by Shapero - Sokol (1982), explains the entrepreneurial intention by perceived desirability, perceived feasibility, and the propensity to act. The theory of planned behaviour was developed by Ajzen (1991) and describes intentions with the help of three determinants: attitude toward the action, perceived behavioural control, and subjective norms. Krueger - Carsrud (1993) developed the entrepreneurial potential model from these models. According to Krueger - Carsrud (1993), Shapero and Sokol's perceived desirability correspond to Ajzen's attitude toward the act and subjective norms, while Ajzens's perceived behavioural control corresponds to Shapero and Sokol's perception of feasibility. Kolvereid $(1996 \mathrm{a}, \mathrm{b})$ demonstrated the applicability of the theory of planned behaviour in entrepreneurship. According to Liñan - Fayolle (2015), the theory of planned behaviour has become the dominant theoretical approach to studying the influencing factors of entrepreneurial behaviour.

There are many articles in the related literature that analyse entrepreneurship or intrapreneurship. Nevertheless, there are few articles which focus on the comparison of the antecedents of both types of entrepreneurial behaviours based on empirical results. In order to stimulate and to enhance the level of entrepreneurial activity in an economy, policymakers might take into account the antecedents of entrepreneurial behaviour. Our findings could support the managers' decision when they want to hire an intrapreneur.

In this paper, we apply the theory of planned behaviour in order to understand and to predict entrepreneurial behaviour of Romanian early-stage entrepreneurs and intrapreneurs, identifying the main differences among them. We estimate logistic regressions in order to identify the influencing factors of the probability of becoming an intrapreneur and an early-stage entrepreneur, and also to determine the differences between these influencing factors.

The paper is organised as follows. We first review the literature related to the theory of planned behaviour applied in entrepreneurship and intrapreneurship. In the subsequent sections, we describe the sample and the research methodology, 
and we present the results of our empirical analysis. Finally, we discuss and interpret our findings, and draw some conclusions, followed by suggestions for further research directions.

\section{LITERATURE REVIEW}

This study aims to contribute to the understanding of differences in entrepreneurial activities, taking account of intrapreneurial activity, which is currently gaining greater recognition.

Pinchot (1985) introduced the term of intrapreneur, defined as an employee in a large corporation empowered to create new products without being constrained by standard procedures. Researchers used terms such as corporate entrepreneurship (Burgelman 1983; Guth - Ginsberg 1990; Sharma - Chrisman 1999) and corporate venturing (Burgelman 1983; MacMillan 1986; Vesper 1990) to describe the entrepreneurial employee activity.

Foba - de Villiers (2007) pointed out that the entrepreneurial initiative is a generator of greater economic activity. The beneficial effect of intrapreneurship on firm performance was demonstrated by many researchers (Covin - Slevin 1986; Zahra 1991; Zahra - Covin 1995; Antoncic - Hisrich 2001; Phan et al. 2009). The influence of intrapreneurship can be related to new business venturing (Hisrich Peters 1986; Antoncic - Hisrich 2001), to innovativeness (Covin - Slevin 1991; Knight 1997; Kuratko et al. 2001; Renko et al. 2009; Alpkan et al. 2010), to the self-renewal of the organization through the redefinition of business concepts, reorganization, and the redefinition and redesign of systems to foster innovation (Guth - Ginsberg 1990; Zahra - Gravis 2000; Kuratko et al. 2001). It also can be associated with proactiveness, which refers to the extent to which organisations attempt to lead rather than follow competitors in such key business areas as the introduction of new products or services, operating technologies and administrative techniques, to risk-taking, and to competitive aggressiveness (Covin - Slevin 1986; Knight 1997; Antoncic 2003).

According to de Jong - Wennekers (2008), the main differences between intrapreneurship and entrepreneurship are the investment of personal financial means and the related financial risk-taking, a higher degree of autonomy, and legal and fiscal aspects of establishing a new independent business. In order to point out the reasons why an individual would choose intrapreneurship over entrepreneurship, we have to identify the influencing factors of becoming an intrapreneur and an entrepreneur, in our case an early-stage entrepreneur. According to Douglas - Fitzsimmons (2008), very little attention has been paid to the formation of intrapreneurial intentions. 
One of the most influential frameworks for the study of entrepreneurial behaviour is the theory of planned behaviour developed by Ajzen (1991). This theory explains entrepreneurial behaviour by intention, which is determined by the combination of the attitude towards the behaviour, subjective norms, and the perceived behavioural control. The attitude toward any action concerns the beliefs about the likely consequences or other attributes of entrepreneurial behaviour, the subjective norms measure the perceived social pressure whether or not to engage in entrepreneurial behaviour, while perceived behavioural control is related to the perceived ease or difficulty of engaging in entrepreneurial behaviour. Thus, behavioural intention is assumed to be the immediate antecedent of behaviour. Behavioural intentions are excluded from our research model since the focus of our study is the actual entrepreneurial behaviour.

The attitude toward entrepreneurial behaviour indicates the degree to which an individual holds a positive or a negative perception about being an entrepreneur. Those who see good opportunities for starting a new business and accept more risk have a positive attitude toward entrepreneurship. Kirzner (1997) showed that entrepreneurial opportunities exist primarily because different members of society have different beliefs about the relative value of resources. Shane - Venkataraman (2000) suggest that the probability that particular people will discover particular opportunities is influenced by the possession of the prior information necessary to identify an opportunity and by the cognitive properties necessary to value it. According to Coduras et al. (2008), the probability of entrepreneurial intention is higher for people who recognize opportunities to start up and for people with a lower degree of risk aversion. As suggested by Nishimura - Tristan (2011), individuals who do not believe that there will be good opportunities will probably not be interested in engaging in an entrepreneurial activity and therefore will not have a positive attitude toward entrepreneurship. They also stated that individuals who think that fear of failure would not prevent them from starting a business will probably be interested in engaging in entrepreneurial activity and will therefore have a positive attitude toward entrepreneurship. Douglas - Fitzsimmons (2013) found that intrapreneurs are more risk-averse than entrepreneurs.

We therefore establish the following hypotheses:

H1a: Individuals with a positive attitude toward entrepreneurship (those who recognize good opportunities and the fear of failure would not prevent them from starting a new business) are more likely to start a new business. 
H1b: Individuals with a positive attitude toward entrepreneurship (those who recognize good opportunities and the fear of failure would not prevent them from starting a new business) are more likely to become intrapreneurs.

H1c: Positive attitude toward entrepreneurship is more likely associated with early-stage entrepreneurs than intrapreneurs.

Subjective norms measure the perceived social pressure of whether or not to engage in entrepreneurial activity. Levie et al. (2010) showed that the effectiveness of initiatives designed to provide entrepreneurial skills will be increased or enhanced by more positive social norms and values. They found no statistically significant differences between intrapreneurs and early-stage entrepreneurs with respect to the following two measures of societal attitudes: entrepreneurship is perceived as a good career choice and successful entrepreneurs have high level of status and respect (Nyström 2012; Benyovszki et al. 2013). Individuals who perceive that society is entrepreneurially supportive will be engaged in entrepreneurial activity with a higher probability. In our opinion, a society could be perceived entrepreneurially supportive if being an entrepreneur is considered a good career choice and entrepreneurs would receive high status and respect.

On this basis, we expect the following:

H2a: Perceived subjective norms are positively related to entrepreneurial behaviour.

H2b: Perceived subjective norms are positively related to intrapreneurial behaviour.

H2c: Early-stage entrepreneurs perceive society as being more entrepreneurially supportive than intrapreneurs.

The perceived behavioural control measures the entrepreneurial ability of an individual. According to Nishimura - Tristan (2011), individuals who do not believe that they have the knowledge, skills, and experience to start a new business will perceive that they have less control over the process of starting a business. Douglas - Fitzsimmons (2008) claimed that entrepreneurial self-efficacy is positively and significantly related to both forms of entrepreneurial behaviour, but has a stronger relationship with entrepreneurial intentions than with intrapreneurial intentions. Nyström (2012) argued that the most pronounced difference between entrepreneurs and intrapreneurs is the perceived knowledge, skills, and experience required to start a new business, which is higher in case of entrepreneurs. 
These arguments are summarised in our final hypotheses:

H3a: Perceived entrepreneurial ability is positively related to entrepreneurial behaviour.

H3b: Perceived entrepreneurial ability is positively related to intrapreneurial behaviour.

H3c: Entrepreneurial self-efficacy is more related to early-stage entrepreneurs than to intrapreneurs.

Among socio-demographic characteristics, gender, age, and education have been shown to play some role in entrepreneurial behaviour. Crant (1996) argued that entrepreneurial intentions were often associated with gender. Males are more adventurous in experimenting with their careers, while females are constrained by family responsibilities and less likely to be engaged in entrepreneurial activity (Blanchflower 2004; Langowitz - Minniti 2007; Benyovszki et al. 2013). The results obtained by Kacperczyk (2013) suggest that women are more likely to pursue intrapreneurship than start-up entrepreneurship because they can make use of maternity benefits. Adachi - Hisada (2016) found that women may be disadvantaged for becoming entrepreneurs and intrapreneurs.

The probability of creating a new venture has been shown to increase with age up to a threshold point and to decrease thereafter (Levesque - Minniti 2006; Benyovszki et al. 2013). Younger and older employees are significantly more likely to engage in nascent intrapreneurship than in nascent entrepreneurship (Parker 2011); however, the literature on organisational behaviour provides mixed results on the impact of age (Bindl - Parker 2010). De Jong et al. (2011) proved that openness to new experiences and change decreases with age, implying a negative relationship between age and motivation. He also pointed out that perceived capability, indicated by experiences in the workplace, increases with age.

There is a mixed pattern between entrepreneurship and education. Some studies report that the education is positively related with the likelihood of engaging in entrepreneurship (Parker 2011; Block et al. 2013). In other studies, entrepreneurship is negatively associated with education (Blanchflower 2004; van Praag et al. 2009). This could be possible since more highly educated individuals are more likely to be offered managerial jobs.

According to Alpkan et al. (2010), the improvement of human capital and education can result in a higher level of organisational innovativeness. Bosma et al. (2013) showed that entrepreneurial employee activity is particularly prevalent among more highly educated employees with high levels of income. 


\section{METHODOLOGY AND DATA}

\subsection{Sample}

The data for this study were constructed from Global Entrepreneurship Monitor (GEM) Romanian Adult Population Survey (APS) database for the 2011-2014 time periods, a survey which is nationally representative. Each year, the target size of the sample is 2,000 individuals aged between 18 and 99 years. Mobile telephones and fixed line telephones are used for the survey. The combination of fixed and mobile lines was necessary since fixed line telephone coverage for the population is estimated at only $54 \%$, while mobile coverage at $80 \%$. The sample was generated using random digit dialling for both fixed line and mobile numbers. Respondent selection from within the household used the next birthday method for fixed line telephones. Mobile telephones directly sampled the person who answered. In the case of households that did not answer when first contacted there were five call backs. Extensive stratification was used (for a total of 98 different strata in 2011 and 2012, and 107 in 2013 and 2014). This was based on 18 cultural areas and 9 types of localities (4 urban types and 5 rural types) defined by the level of social-economic development. The surveys are conducted at the same time in each year, between May and June, using a standardized questionnaire developed by the Global Entrepreneurship Monitor consortium.

We selected those individuals from the database who were aged between 18 and 64 years, and who were not simultaneously early-stage entrepreneurs and entrepreneurial employees (intrapreneurs). As a result, the sample size for estimation is 7,268 adults from Romania, with 570 early-stage entrepreneurs and 490 intrapreneurs.

\subsection{Measures}

The questionnaire of the Adult Population Survey contains some items which allow us to measure the theory of planned behaviour variables. Our research model does not contain entrepreneurial intentions since our main concern is entrepreneurial behaviour, i.e. those who are involved in entrepreneurial activity.

\section{Entrepreneurial behaviour}

According to the GEM methodology, early-stage entrepreneurs are those individuals in the working age population who are actively involved in business startups, either in the phase in advance of the birth of the firm (nascent entrepreneurs), 
or in the phase spanning the 42 months after the birth of the firm (owner-managers of new firms). The payment of any wages for more than three months defines the birth event of the firm (Amorós - Bosma 2014).

GEM operationalizes intrapreneurs as employees who are actively involved in and had a leading role in either the idea development for a new activity, or the preparation and implementation of a new activity (Singer et al. 2015).

Following the theory of planned behaviour, the three determinants of entrepreneurial behaviour are attitude toward entrepreneurship, subjective norms, and perceived behavioural control.

\section{Attitude toward entrepreneurship (ATE)}

The GEM questionnaire contains two items, which help us measure the attitude toward entrepreneurial action. One of them concentrates on the positive attitude toward entrepreneurship. The respondents were asked if they see good opportunities in the next six months for starting a new business in the area where they live. Respondents who see good opportunities for venture creation have positive attitude toward entrepreneurship. The focus of the other item is negative attitude toward entrepreneurship, namely risk aversion. The questioned persons were asked whether fear of failure would prevent them from starting a business or not. Those who consider that fear of failure would be an obstacle in starting a new venture, have a negative attitude toward entrepreneurship. The possible responses were "yes" or "no" in the case of each item.

These variables allowed us to create the measure of attitude toward entrepreneurship. We consider that a respondent has a positive attitude if he or she sees good opportunities and fear of failure would not prevent him or her from starting a new business; in all other cases, we identify a negative attitude toward entrepreneurship. This variable is a binary variable, "1" indicating a positive attitude ("yes" response to opportunity recognition and "no" response that fear of failure would be an obstacle in starting a venture).

\section{Subjective norm (SN)}

With respect to entrepreneurship, the subjective norm is the perceived image of entrepreneurship in society. According to Ajzen (2005), the subjective norm is a person's perception of social pressure whether or not to engage in the behaviour under consideration. An entrepreneurially supportive society motivates people to start a new business. We measured the subjective norm based on two assertions: "Starting a business is considered a good career choice" and "Persons growing a successful new business receive high status". We consider a society as being 
entrepreneurially supportive if being an entrepreneur is considered a good career choice and successful entrepreneurs receive high status and respect. The subjective norm variable is a binary variable, " 1 " indicating a positive image of entrepreneurs in society ("yes" response to both).

\section{Perceived behavioural control (PBC)}

In this study, perceived entrepreneurial ability is measured with the following assertions: "You have the knowledge, skills, and experience required to start a new business". The perceived behavioural control was coded as a binary variable with the value " 1 " if the answer was "yes" and " 0 " in case of a negative answer. The more individuals consider that they possess the required skills, knowledge, and experience to create a new venture, the more they perceive that they have the control over the firm starting process.

\section{Control variables}

We used a set of socio-demographic variables which have an influence on entrepreneurial behaviour according to the literature. Our control variables were measured as follows:

- Age: the respondents were asked to indicate the range that describes their age. There are five age categories: $18-24,25-34,35-44,45-54,55-64$ years old.

- Sex (1 = Male, 2 = Female $)$.

- Education level: the respondents were asked to provide the highest level of education they had completed. The educational attainment is a four-category variable $(1=$ Some secondary education, $2=$ Secondary degree, $3=$ Postsecondary education, $4=$ Graduate degree).

\subsection{Methodology}

The logit regression model estimates the probability of an individual belonging to a certain group or not. This regression model also identifies the most important factors which explain the differences between both groups.

According to Hosmer and Lemeshow (2000), a logit regression is a multiple regression with an outcome variable that is a categorical dichotomy and predictor variables that are continuous or categorical. The multiple logit regressions for this study take the following form: 


$$
\pi(X)=\frac{e^{g(X)}}{1+e^{g(X)}},
$$

where $\pi(X)=P(Y=1 \mid X)$ is the conditional probability that the outcome is present, $Y$ is the dependent variable, $X$ is the vector of the independent variables $X=\left(X_{1}, \ldots, X_{n}\right)$, and $g(X)=\beta_{0}+\beta_{1} x_{1}+\cdots+\beta_{n} x_{n}$ is the linear combination of the independent variables, where $\beta_{0}, \beta_{1}, \ldots, \beta_{n} \in R$ are real regression coefficients.

The dependent and explanatory variables are shown in Table 1.

Table 1. Dependent and explanatory variables in the models

\begin{tabular}{|c|c|c|c|}
\hline Notation & Name & Description & Values \\
\hline \multicolumn{4}{|c|}{ DEPENDENT VARIABLES } \\
\hline TEA & $\begin{array}{l}\text { Early-stage } \\
\text { entrepreneurial rate }\end{array}$ & $\begin{array}{l}\text { Refers to the adult population aged } \\
\text { between } 18-64 \text { years, identified } \\
\text { as nascent (individuals who are } \\
\text { actively planning a new venture) } \\
\text { or young business entrepreneurs } \\
\text { (entrepreneurs who at least partly } \\
\text { own and manage a new business } \\
\text { that is between } 4 \text { and } 42 \text { months } \\
\text { old and have not paid salaries for } \\
\text { longer than this period) }\end{array}$ & $\begin{array}{l}0=\text { No } \\
1=\text { Yes }\end{array}$ \\
\hline EEA & $\begin{array}{l}\text { Intrapreneurial } \\
\text { (entrepreneurial } \\
\text { employee) activity } \\
\text { rate }\end{array}$ & $\begin{array}{l}\text { Employees developing new } \\
\text { activities for their main employer } \\
\text { such as developing or launching } \\
\text { new goods or services, or setting } \\
\text { up a new business unit, a new } \\
\text { establishment, or subsidiary }\end{array}$ & $\begin{array}{l}0=\text { No } \\
1=\text { Yes }\end{array}$ \\
\hline TEA_EEA & $\begin{array}{l}\text { Type of } \\
\text { entrepreneurial } \\
\text { activity }\end{array}$ & $\begin{array}{l}\text { Indicates if the individual is } \\
\text { an early-stage entrepreneur or } \\
\text { intrapreneur }\end{array}$ & $\begin{array}{l}0=\text { TEA } \\
1=\text { EEA }\end{array}$ \\
\hline \multicolumn{4}{|c|}{ EXPLANATORY VARIABLES } \\
\hline \multicolumn{4}{|c|}{ Socio-demographic variables } \\
\hline AGE & Age & Age categories & $\begin{array}{l}1=18-24,2=25-34 \\
3=35-44,4=45-54 \\
5=55-64\end{array}$ \\
\hline SEX & Gender & Gender of the individual & $\begin{array}{l}1=\text { Male } \\
2=\text { Female } \\
\end{array}$ \\
\hline EDUC & Education & $\begin{array}{l}\text { The highest educational attainment } \\
\text { of the respondent }\end{array}$ & $\begin{array}{l}1=\text { Some secondary } \\
2=\text { Secondary degree } \\
3=\text { Post-secondary } \\
4=\text { Graduate } \\
\text { experience }\end{array}$ \\
\hline
\end{tabular}


Table 1. continued

\begin{tabular}{|c|c|c|c|}
\hline Notation & Name & Description & Values \\
\hline \multicolumn{4}{|c|}{ Perceptional variables } \\
\hline OPPORT & $\begin{array}{l}\text { Opportunity } \\
\text { perception }\end{array}$ & $\begin{array}{l}\text { The respondents answered if they } \\
\text { see good business opportunities for } \\
\text { the next } 6 \text { months }\end{array}$ & $\begin{array}{l}0=\mathrm{No} \\
1=\text { Yes }\end{array}$ \\
\hline PBC & $\begin{array}{l}\text { Perceived } \\
\text { behavioural control - } \\
\text { Perception regarding } \\
\text { the trust in own } \\
\text { entrepreneurial skills }\end{array}$ & $\begin{array}{l}\text { The respondents answered if } \\
\text { they consider that they have the } \\
\text { necessary knowledge to set and } \\
\text { manage an own business }\end{array}$ & $\begin{array}{l}0=\mathrm{No} \\
1=\text { Yes }\end{array}$ \\
\hline FEARFAIL & $\begin{array}{l}\text { Perception of fear of } \\
\text { failure }\end{array}$ & $\begin{array}{l}\text { The respondents answered if they } \\
\text { consider that fear of failure would } \\
\text { prevent them from starting a } \\
\text { business }\end{array}$ & $\begin{array}{l}0=\mathrm{No} \\
1=\text { Yes }\end{array}$ \\
\hline NBGOOD & Good career choice & $\begin{array}{l}\text { Starting a business is considered as } \\
\text { a good career choice }\end{array}$ & $\begin{array}{l}0=\mathrm{No} \\
1=\text { Yes }\end{array}$ \\
\hline NBSTAT & High status & $\begin{array}{l}\text { Persons growing a successful new } \\
\text { business receive high status }\end{array}$ & $\begin{array}{l}0=\text { No } \\
1=\text { Yes }\end{array}$ \\
\hline ATE & $\begin{array}{l}\text { Attitude toward } \\
\text { entrepreneurship }\end{array}$ & $\begin{array}{l}\text { The respondents answered that they } \\
\text { see good business opportunities } \\
\text { for the next } 6 \text { months and they } \\
\text { consider that fear of failure would } \\
\text { not prevent them from starting a } \\
\text { business }\end{array}$ & $\begin{array}{l}0=\mathrm{No} \\
1=\text { Yes }(\mathrm{OPPORT}=1 \\
\& \text { FEARFAIL }=0)\end{array}$ \\
\hline $\mathrm{SN}$ & Subjective norms & $\begin{array}{l}\text { The respondents affirmed that in } \\
\text { their opinion, Romanian society } \\
\text { considers starting a new business a } \\
\text { good career choice and successful } \\
\text { entrepreneurs receive high status }\end{array}$ & $\begin{array}{l}0=\mathrm{No} \\
1=\text { Yes }(\mathrm{NBGOOD}=1 \\
\& \text { NBSTAT }=1)\end{array}$ \\
\hline
\end{tabular}

Source: GEM, Adult Population Survey.

\section{EMPIRICAL RESULTS}

Table 2 shows the distribution of intrapreneurs and early-stage entrepreneurs according to the socio-demographic variables. The relationship between age and entrepreneurship is known as an inverse U-shape (Lévesque - Minniti 2006; Kautonen et al. 2015; Adachi - Hisada 2016). We have found an inverse Ushaped relationship, too. In accordance with Parker (2011), there is a statistically significant difference between intrapreneurship and early-stage entrepreneurship according to age in the case of younger and older employees. The prevalence rate of males is significantly higher in case of early-stage entrepreneurs. We found that intrapreneurs have a significantly higher level of education. Almost half of them have masters or doctoral degrees. 
Table 2. The socio-demographic characteristics of Romanian intrapreneurs and early-stage entrepreneurs (\%)

\begin{tabular}{|l|l|c|c|}
\hline \multicolumn{2}{|c|}{} & $\begin{array}{c}\text { Early-stage } \\
\text { entrepreneurs }\end{array}$ & Intrapreneurs \\
\hline \multirow{4}{*}{ Age categories } & $18-24$ years & $\mathbf{1 8 . 8}$ & $\mathbf{9 . 8}$ \\
\cline { 2 - 4 } & 25-34 years & 33.0 & 29.6 \\
\cline { 2 - 4 } & $35-44$ years & 23.0 & 27.1 \\
\cline { 2 - 4 } & 45-54 years & $\mathbf{1 6 . 8}$ & $\mathbf{2 3 . 5}$ \\
\cline { 2 - 4 } & 55-64 years & 8.4 & 10.0 \\
\hline \multirow{3}{*}{$\begin{array}{l}\text { Sex } \\
\text { attainment }\end{array}$} & Male & $\mathbf{6 5 . 6}$ & $\mathbf{5 6 . 5}$ \\
\cline { 2 - 4 } & Female & $\mathbf{3 4 . 4}$ & $\mathbf{4 3 . 5}$ \\
\cline { 2 - 4 } & Some secondary & $\mathbf{4 . 3}$ & $\mathbf{0 . 8}$ \\
\cline { 2 - 4 } & Secondary degree & $\mathbf{2 5 . 0}$ & $\mathbf{1 8 . 4}$ \\
\cline { 2 - 4 } & Post-secondary & 37.0 & 32.9 \\
\cline { 2 - 4 } & Graduate expectation & $\mathbf{3 3 . 8}$ & $\mathbf{4 7 . 8}$ \\
\hline
\end{tabular}

Note:Statistically significant differences are highlighted in bold.

Source: Own calculation based on the GEM Romania, Adult Population Survey, 2011-2014.

Analysing the differences between intrapreneurs and early-stage entrepreneurs regarding the determinants of entrepreneurial behaviour (Table 3), we found that the proportion of early-stage entrepreneurs who see good opportunities for starting a new venture in the following six months is significantly higher than in case of intrapreneurs. There is no significant difference between the proportion of those early-stage entrepreneurs and intrapreneurs who consider that fear of failure would prevent them from starting a new business. The proportion of earlystage entrepreneurs with a positive attitude toward entrepreneurship is signifi-

Table 3. Entrepreneurial perceptions of Romanian intrapreneurs and early-stage entrepreneurs (\%)

\begin{tabular}{l|c|c}
\hline & $\begin{array}{c}\text { Early-stage } \\
\text { entrepreneurs }\end{array}$ & Intrapreneurs \\
\hline $\begin{array}{l}\text { Sees good opportunities for starting a business in the next } \\
\text { six months }\end{array}$ & $\mathbf{4 7 . 3}$ & $\mathbf{3 7 . 6}$ \\
\hline Fear of failure would prevent starting a business & 36.8 & 42.4 \\
\hline Attitude toward entrepreneurship (ATE) & $\mathbf{3 2 . 4}$ & $\mathbf{2 4 . 4}$ \\
\hline Starting a business is considered as a good career choice & $\mathbf{6 9 . 5}$ & $\mathbf{6 2 . 1}$ \\
\hline $\begin{array}{l}\text { Persons growing a successful new business receive high } \\
\text { status }\end{array}$ & 70.1 & 64.5 \\
\hline Subjective norms (SN) & $\mathbf{5 0 . 5}$ & $\mathbf{4 1 . 0}$ \\
\hline $\begin{array}{l}\text { Has the required knowledge/skills to start a business } \\
\text { (PBC) }\end{array}$ & $\mathbf{8 2 . 4}$ & $\mathbf{6 4 . 6}$ \\
\hline
\end{tabular}

Note: Statistically significant differences are highlighted in bold.

Source: Own calculation based on the GEM Romania, Adult Population Survey, 2011-2014. 
cantly higher than in the case of intrapreneurs. In accordance with the results of Nyström (2012), there are no statistically significant differences between intrapreneurs and early-stage entrepreneurs with respect to perceptions about the high status of successful entrepreneurs. The proportion of early-stage entrepreneurs who perceive that society is entrepreneurially supportive is significantly higher than in case of intrapreneurs. The perceived entrepreneurial ability also differs significantly in the case of these venture creators, early-stage entrepreneurs perceiving in higher proportion that they have the necessary skills and knowledge to start a new business.

The correlations between the variables are shown in Table 4. The correlation matrix offers preliminary support for our hypotheses. Indeed, most of the correlations between entrepreneurial behaviour and each of its hypothesized determinants are significant and in the expected direction.

Table 4. Spearman correlation matrix

\begin{tabular}{l|c|c|c|c|c|c|c|c|c}
\hline & TEA & EEA & TEA_EEA & Education & AGE & Sex & PBC & ATE & SN \\
\hline TEA & 1.000 & $-0.078^{* * * *}$ & $-1.000^{* * *}$ & $0.092^{* * *}$ & $-0.083^{* * * *}$ & $-0.093^{* * *}$ & $0.235^{* * *}$ & $0.101^{* * * *}$ & -0.016 \\
\hline EEA & & 1.000 & $1.000^{* * *}$ & $0.167^{* * *}$ & -0.014 & $-0.045^{* * * *}$ & $0.120^{* * * *}$ & $0.046^{* * * *}$ & $-0.068^{* * * *}$ \\
\hline TEA_EEA & & & 1.000 & $0.158^{* * * *}$ & $0.134^{* * * *}$ & $0.079^{* * *}$ & $-0.202^{* * * *}$ & $-0.076^{* * *}$ & $-0.097^{* * *}$ \\
\hline Education & & & & 1.000 & $-0.094^{* * *}$ & $0.032^{* * * *}$ & $0.241^{* * * *}$ & 0.006 & $-0.163^{* * * *}$ \\
\hline AGE & & & & & 1.000 & 0.016 & $-0.043^{* *}$ & $-0.101^{* * *}$ & $-0.022^{*}$ \\
\hline Sex & & & & & & 1.000 & $-0.185^{* * * *}$ & $-0.086^{* * * *}$ & $0.047^{* * *}$ \\
\hline PBC & & & & & & & 1.000 & $0.114^{* * * *}$ & $-0.077^{* * *}$ \\
\hline ATE & & & & & & & & 1.000 & $0.080^{* * *}$ \\
\hline SN & & & & & & & & & 1.000 \\
\hline
\end{tabular}

Notes: *** Correlation is significant at the 0.01 level (2-tailed); ** Correlation is significant at the 0.05 level (2-tailed); ${ }^{*}$ Correlation is significant at the 0.1 level (2-tailed).

Source: Own calculation based on the GEM Romania, Adult Population Survey, 2011-2014.

Table 5 shows the results of the estimated logit regressions. In the first two models, entrepreneurial behaviour (being an early-stage entrepreneur, being an intrapreneur) is the dependent variable and the independent variables are attitude toward entrepreneurship, subjective norm, and perceived behavioural control. We used age, sex, and educational attainment in each estimated model as control variables.

Model 1 of Table 5 presents the estimated probability of becoming an earlystage entrepreneur. This is higher if the individual is male, has a higher educational level, younger, if the individual thinks that he/she possesses the required skills and knowledge to create a new venture, and has a positive attitude toward entrepreneurship. In line with Parker (2011) and Block et al. (2013), we found that the relationship between education and the probability of becoming an early-stage entrepreneur is positive. We found no significant influence of subjective norms 
Table 5. Influencing factors of becoming an early-stage entrepreneur, respectively of becoming an intrapreneur

\begin{tabular}{l|c|c|c|c|c|c|c|c|c}
\hline & \multicolumn{3}{|c|}{ Model 1 (TEA) } & \multicolumn{3}{c|}{ Model 2 (EEA) } & \multicolumn{3}{c}{ Model 3 (TEA_EEA) } \\
\hline & B & Sig. & $\operatorname{Exp}(\mathrm{B})$ & B & Sig. & $\operatorname{Exp}(\mathrm{B})$ & B & Sig. & $\operatorname{Exp(B)}$ \\
\hline Education & 0.193 & 0.001 & 1.213 & 0.715 & 0.000 & 2.044 & 0.430 & 0.000 & 1.537 \\
\hline Age & -0.251 & 0.000 & 0.778 & -0.018 & 0.649 & 0.982 & 0.258 & 0.000 & 1.294 \\
\hline Sex & -0.462 & 0.000 & 0.630 & -0.273 & 0.011 & 0.761 & 0.149 & 0.313 & 1.161 \\
\hline ATE & 0.483 & 0.000 & 1.621 & 0.343 & 0.005 & 1.409 & -0.077 & 0.630 & 0.926 \\
\hline SN & -0.042 & 0.680 & 0.959 & -0.358 & 0.001 & 0.699 & -0.326 & 0.026 & 0.722 \\
\hline PBC & 1.728 & 0.000 & 5.628 & 0.519 & 0.000 & 1.680 & -1.155 & 0.000 & 0.315 \\
\hline Constant & -2.776 & 0.000 & 0.062 & -4.441 & 0.000 & 0.012 & -1.403 & 0.001 & 0.246 \\
\hline Nagelkerke R ${ }^{2}$ & \multicolumn{4}{|c|}{0.161} & \multicolumn{3}{c|}{0.097} & \multicolumn{4}{c}{0.135} \\
\hline
\end{tabular}

Source: Own calculation based on GEM Romania, Adult Population Survey, 2011-2014.

on the probability of becoming an early-stage entrepreneur. Based on Model 1, we evaluate $\mathrm{H} 1 \mathrm{a}, \mathrm{H} 2 \mathrm{a}$, and $\mathrm{H} 3 \mathrm{a}$. Our results support $\mathrm{H} 1 \mathrm{a}$ : we see a positive effect of attitude toward entrepreneurship on the early-stage entrepreneurial behaviour. $\mathrm{H} 2 \mathrm{a}$ is rejected, since the perceived subjective norms do not have a significant influence on the probability of becoming an early-stage entrepreneur. The idea of $\mathrm{H3a}$ is also supported; the perceived entrepreneurial control (perceived entrepreneurial skills and knowledge) similarly has a positive effect: the more an individual thinks that he or she possesses these skills, the more confident he/she can be about starting a successful new business.

Model 2 of Table 5 presents the estimated probability of becoming an intrapreneur. This is higher if the individual is male, has a higher educational level, if the individual thinks that he or she possesses the required skills and knowledge to create a new venture, has a positive attitude toward entrepreneurship, and perceives society as being entrepreneurially supportive. In accordance with Bosma et al. (2013) and Alpkan et al. (2010), we found that educational level has a positive influence on becoming an intrapreneur and that more educated entrepreneurial employees can result in more innovation to the organisation. We found no significant influence of age on the probability of becoming an intrapreneur. Based on Model 2, we evaluate $\mathrm{H} 1 \mathrm{~b}, \mathrm{H} 2 \mathrm{~b}$, and $\mathrm{H} 3 \mathrm{~b}$. Our results support $\mathrm{H} 1 \mathrm{~b}$ and $\mathrm{H} 3 \mathrm{~b}$. We can observe a positive effect of attitude toward entrepreneurship and of the perceived entrepreneurial control on intrapreneurial behaviour. $\mathrm{H} 2 \mathrm{~b}$ is rejected, since the perceived subjective norms have a significant negative influence on the probability of becoming an intrapreneur.

In order to emphasise the main differences between early-stage entrepreneurs and intrapreneurs regarding the determinants of entrepreneurial behaviour in the theory of planned behaviour, we estimated Model 3 of Table 5. The dependent variable of this regression model is also a dichotomous variable, taking the value 
" 0 " if the individual is an early-stage entrepreneur and the value " 1 " if the individual is an intrapreneur. We used the same control variables as in case of Model 1 and Model 2. H1c, H2c, and $\mathrm{H} 3 \mathrm{c}$ are evaluated using the results of this model. $\mathrm{H} 2 \mathrm{c}$ and $\mathrm{H} 3 \mathrm{c}$ are supported by Model 3. H1c is rejected, since the attitude toward entrepreneurship of early-stage entrepreneurs and intrapreneurs does not differ significantly. The SN and PBC variables are statistically significant with a negative sign, which reflect that early-stage entrepreneurs perceive society as being more entrepreneurially supportive than intrapreneurs, and that entrepreneurial self-efficacy is related more to early-stage entrepreneurs than to intrapreneurs. Concerning the control variables, we can observe that age and education are statistically significant. Their positive sign suggests that intrapreneurs are more educated and older than early-stage entrepreneurs. In this regression, the influence of gender is not significant, due to the fact that the distribution by gender of earlystage entrepreneurs and intrapreneurs do not differ significantly.

According to the Nagelkerke $\mathrm{R}^{2}$, the variance of the entrepreneurial behaviour is explained between $9.7 \%$ and $16.1 \%$ by the variables of the theory of planned behaviour.

According to Model 1 and Model 2, the strongest influence from the variables of the theory of planned behaviour on entrepreneurial behaviour is exerted by perceived behavioural control (PBC). In case of early-stage entrepreneurs, the impact is more considerable, the odds ratio $(\operatorname{Exp}(\mathrm{B}))$ being 5.628, meaning that self-confident individuals are 5.628 times more likely to become early-stage entrepreneurs.

\section{CONCLUSIONS AND DISCUSSION}

We applied the theory of planned behaviour in order to understand and to predict entrepreneurial behaviour of Romanian early-stage entrepreneurs and intrapreneurs, identifying the main differences among them based on the Romanian 2011-2014 GEM Adult Population Survey database. Another purpose of the study was to test the applicability of the theory of planned behaviour as a predictor of entrepreneurial behaviour within the context of the Global Entrepreneurship Monitor research project in Romania.

We can conclude that in the case of early-stage entrepreneurs, the theory of planned behaviour is partially supported. Only the attitude toward entrepreneurship (ATE) and perceived behavioural control (PBC) had a significant effect on early-stage entrepreneurial behaviour. These results are in line with the findings of Coduras et al. (2008), Nishimura - Tristan (2011), Douglas - Fitzsimmons (2013). The perceived image of entrepreneurs does not have a significant impact 
on the probability of becoming an early-stage entrepreneur. A similar view is held by Nishimura - Tristan (2011).

The theory of planned behaviour was supported in the case of intrapreneurs. In contrast to our prior expectation, subjective norms have a negative effect on the probability of becoming an intrapreneur. This finding suggests that the more entrepreneurially supportive a society, the less the probability of becoming an intrapreneur. Attitude toward entrepreneurship (ATE) and perceived entrepreneurial ability (PBC) have a positive significant effect on the probability of becoming an intrapreneur.

Our empirical results show that there are statistically significant differences between intrapreneurs and early-stage entrepreneurs according to the perception about the entrepreneurial supportiveness of society. Early-stage entrepreneurs consider the perceived image of an entrepreneur in society to be more positive. The most pronounced difference between early-stage entrepreneurs and intrapreneurs was found in the case of entrepreneurial ability, due to the fact that earlystage entrepreneurs are more self-confident, which is supported also by Nyström (2012). The perceived attitude toward entrepreneurship of society is similar in the case of early-stage entrepreneurs and intrapreneurs.

In accordance with our results, we can affirm that the theory of planned behaviour provides a good theoretical background for emphasising the main differences between early-stage entrepreneurs and intrapreneurs.

Our work had its limitations. In the theory of planned behaviour, the subjective norms refer to the perceptions about performing the behaviour of those people who are important for the individual. Since the GEM survey does not contain questions regarding this aspect, this factor was measured by the perception of society about entrepreneurship in our study. We measured the subjective norm relying on two assertions: "Starting a business is considered as a good career choice" and "Persons growing a successful new business receive high status". We considered that a society is entrepreneurially supportive if being an entrepreneur is considered a good career choice and successful entrepreneurs receive high status and respect.

Regarding the outstanding role of intrapreneurs as a further research theme, the difference between entrepreneurial employees and other employees could be of great interest, which can lead to identifying potential intrapreneurs among the employees of an organisation. 


\section{REFERENCES}

Adachi, T. - Hisada, T. (2016): Gender Differences in Entrepreneurship and Intrapreneurship: An Empirical Analysis. Small Business Economics, Doi:10.1007/S11187-016-9793-Y

Ajzen, I. (1991): The Theory of Planned Behavior. Organizational Behavior and Human Decision Making Processes, 50(2): 179-211.

Ajzen, I. (2005): Attitudes, Personality and Behaviour. London: Mcgraw-Hill Education.

Alpkan, L. - Bulut, C. - Gunday, G. - Ulusoy, G. - Kilic, K. (2010): Organizational Support for Intrapreneurship and Its Interaction with Human Capital to Enhance Innovative Performance. Management Decision, 48(5): 732-755.

Amorós, J. E. - Bosma, N. (2014): Global Entrepreneurship Monitor. 2013 Global Report. Babson College, Universidad Del Desarrollo, UniversitiTun Abdul Razak, and Global Entrepreneurship Research Consortium (GERA).

Antoncic, B. (2003): Risk Taking in Intrapreneurship: Translating the Individual Level Risk Aversion into the Organizational Risk Taking. Journal of Enterprising Culture, 11(1): 1-23.

Antoncic, B. - Hisrich, R. D. (2001): Intrapreneurship: Construct Refinement and Cross-Cultural Validation. Journal of Business Venturing, 16(5): 495-527.

Benyovszki, A. - Nagy, Á. - Petru, T. P. (2013): Is There a Difference between Intrapreneurs and Early-Stage Entrepreneurs in Romania? Theoretical and Applied Economics, 6(583): 53-60.

Bindl, U. K. - Parker, S. K. (2010): Proactive Work Behaviour: Forward-Thinking and ChangeOriented Action in Organization. APA Handbook of Industrial and Organizational Psychology, 2: 567-598.

Blanchflower, D. G. (2004): Self-Employment: More may not Be Better. NBER Working Paper, No. 10286.

Block, J. H. - Hoogerheide, L. - Thurik, R. (2013): Education and Entrepreneurial Choice: An Instrumental Variables Analysis. International Small Business Journal, 31(1): 23-33.

Bosma, N. S. - Wennekers, S. - Guerrero, M. - Amorós, J. E. - Martiarena, A. - Singer, S. (2013): The Global Entrepreneurship Monitor. Special Report on Entrepreneurial Employee Activity. Global Entrepreneurship Research Association.

Burgelman, R. A. (1983): Corporate Entrepreneurship and Strategic Management: Insights from a Process Study. Management Science, 29(12): 1349-1364.

Coduras, A. - Urbano, D. - Rojas, A. - Martinez, S. (2008): The Relationship between University Support to Entrepreneurship with Entrepreneurial Activity in Spain: A Gem Data Based Analysis. International Atlantic Economic Society, 14: 395-406.

Covin, J. G. - Slevin, D. P. (1986): The Development and Testing of an Organizational-Level Entrepreneurship Scale. In: Ronstadt, R. et al. (eds): Frontiers of Entrepreneurship Research. Babson College, Wellesley, MA, pp. 628-639.

Covin, J. G. - Slevin, D. P. (1991): A Conceptual Model of Entrepreneurship as Firm Behaviour. Entrepreneurship Theory and Practice, 16(1): 7-25.

Crant, J. M. (1996): The Proactive Personality Scale as a Predictor of Entrepreneurial Intentions. Journal of Small Business Management, 34: 42-49.

De Jong, J. - Wennekers, S. (2008): Intrapreneurship; Conceptualizing Entrepreneurial Employee Behaviour. Research Report H200802, Zoetermeer: EIM.

De Jong, J. P. J. - Parker, S. - Wennekers, S. - Wu, C. (2011): Corporate Entrepreneurship at the Individual Level: Measurement and Determinants. EIM Research Reports.

Douglas, E. - Fitzsimmons, J. (2008): Individual Intentions towards Entrepreneurship vs. Intrapreneurship. Paper presented at 5th ASGE International Entrepreneurship Research Exchange Conference, Melbourne, February. 
Douglas, E. - Fitzsimmons, J. (2013): Intrapreneurial Intentions vs. Entrepreneurial Intentions: Distinct Constructs with Different Antecedents. Small Business Economics, 41(1): 115-132.

Foba, T. - De Villiers, D. (2007): The Integration of Intrapreneurship into a Performance Management Model. Journal of Human Resource Management, 5(2): 1-8.

Guth, W. D. - Ginsberg, A. (1990): Guest Editors' Introduction: Corporate Entrepreneurship. Strategic Management Journal, 11(5): 5-15.

Hisrich, R. D. - Peters, M. P. (1986): Establishing a New Business Venture Unit within a Firm. Journal of Business Venturing, 1(3): 307-322.

Hosmer, D. W. - Lemeshow, S. (2000): Applied Logistic Regression. (2nd edition). New York, USA: Wiley \& Sons, Inc.

Kacperczyk, A. (2013): Female Entrepreneurship and Alternative Opportunities inside an Established Firm. 35 th DRUID Conference, Barcelona, June 17-19.

Kautonen, T. - Van Gelderen, M. - Fink, M. (2015): Robustness of the Theory of Planned Behavior in Predicting Entrepreneurial Intentions and Actions. Entrepreneurship Theory and Practice, 39(3): 655-647.

Kirzner, I. (1997): Entrepreneurial Discovery and the Competitive Market Process: An Austrian Approach. Journal of Economic Literature, 35(1): 60-85.

Knight, G. A. (1997): Cross-Cultural Reliability and Validity of a Scale to Measure Firm Entrepreneurial Orientation. Journal of Business Venturing, 12(3): 213-225.

Krueger, N. F. Jr. - Carsrud, A. L. (1993): Entrepreneurial Intentions: Applying the Theory of Planned Behaviour. Entrepreneurship \& Regional Development, 5(4): 315-330.

Kuratko, D. F. - Ireland, R. D. - Hornsby, J. S. (2001): Improving Firm Performance through Entrepreneurial Actions: Acordia's Corporate Entrepreneurship Strategy. Academy of Management Executive, 15(4): 60-71.

Langowitz, N. - Minniti, M. (2007): The Entrepreneurial Propensity of Women. Entrepreneurship Theory and Practice, 21(3): 341-364.

Levesque, M. - Minniti, M. (2006): The Effect of Aging on Entrepreneurial Behaviour. Journal of Business Venturing, 21(2): 177-194.

Levie, J. - Hart, M. - Karim, M. S. (2010): Impact of Media on Entrepreneurial Intentions and Actions. Global Entrepreneurship Monitor.

Liñán, F. - Fayolle, A. (2015): A Systematic Literature Review on Entrepreneurial Intentions: Citation, Thematic Analyses, and Research Agenda. International Entrepreneurship and Management Journal, 11(4): 907-933.

MacMillan, I. C. - Block, Z. - Narashima, P. N. S. (1986): Corporate Venturing: Alternatives, Obstacles Encountered, and Experience Effects. Journal of Business Venturing, 1(2): 177-191.

Nishimura, J. S. - Tristan, O. M. (2011): Using the Theory of Planned Behavior to Predict Nascent Entrepreneurship. Academia. Revista Latinoamericana de Administración, 46: 55-71.

Nyström, K. (2012): Entrepreneurial Employees: Are They Different from Independent Entrepreneurs? CESIS Electronic Working Paper Series, No. 281.

Parker, S. C. (2011): Intrapreneurship or Entrepreneurship? Journal of Business Venturing, 26(1): $19-34$.

Phan, P. H. - Wright, M. - Ucbasaran, D. - Tan, W. L. (2009): Corporate Entrepreneurship: Current Research and Future Directions. Journal of Business Venturing, 24(3): 197-205.

Pinchot, G. (1985): Intrapreneuring: Why You don't Have to Leave the Corporation to Become an Entrepreneur. New York: HarperCollins Publisher.

Renko, M. - Carsrud, A. - Brännback, M. (2009): The Effect of a Market Orientation, Entrepreneurial Orientation, and Technological Capability on Innovativeness: A Study of Young Bio- 
technology Ventures in the United States and Scandinavia. Journal of Small Business Management, 47(3): 331-369.

Shane, S. - Venkataraman, S. (2000): The Promise of Entrepreneurship as a Field of Research. Academy of Management Review, 25(1): 217-226.

Shapero, A. - Sokol, L. (1982): Social Dimensions of Entrepreneurship. In: Kent, C. A. - Sexton, D. L. - Vesper, K. H. (eds): Encyclopedia of Entrepreneurship, pp. 72-90. Englewood-Cliffs, NJ: Prentice-Hall.

Sharma, P. - Chrisman, J. J. (1999): Towards a Reconciliation of the Definitional Issues in the Field of Corporate Entrepreneurship. Entrepreneurship Theory and Practice, 23(3): 11-27.

Singer, S. - Amorós, J. E. - Arreola, D. M. (2015): Global Entrepreneurship Monitor 2014 - Global Report. Babson College, Universidad Del Desarrollo, UniversitiTun Abdul Razak, Technológico De Monterrey, London Business School and Global Entrepreneurship Research Consortium (GERA).

Van Praag, M. - Van Witteloostuijn, A. - Van Der Sluis, J. (2009): Returns for Entrepreneurs vs. Employees: The Effect of Education and Personal Control on the Relative Performance of Entrepreneurs vs. Wage Employees. IZA Discussion Paper, No. 4628.

Vesper, K. H. (1990): New Venture Strategies. Englewood-Cliffs, NJ: Prentice-Hall.

Zahra, S. A. (1991): Predictors and Financial Outcomes of Corporate Entrepreneurship: An Exploratory Study. Journal of Business Venturing, 6(4): 259-85.

Zahra, S. A. - Covin, J. C. (1995): Contextual Influences on the Corporate Entrepreneurship-Performance Relationship: A Longitudinal Analysis. Journal of Business Venturing, 10(1): 43-58.

Zahra, S. A. - Gravis, D. M. (2000): International Corporate Entrepreneurship and Firm Performance: The Moderating Effect of International Environmental Hostility. Journal of Business Venturing, 15(5): 469-492. 